\title{
In-vitro synthesis of a low molecular weight lipid-soluble luteotrophic factor by conceptuses of cows at Day 13-18 of pregnancy
}

\author{
G. J. Hickey and W. Hansel \\ Department of Physiology, New York State College of Veterinary Medicine and \\ Division of Biological Sciences, Cornell University, Ithaca, NY 14853, U.S.A.
}

\begin{abstract}
Summary. Two culture systems for maintenance of Day 13-18 conceptus tissue were developed. Harvested culture media were assayed for luteotrophic activity by determining their ability to stimulate progesterone synthesis by dispersed bovine luteal cells. Significant luteotrophic activity was found in $80 \%$ of the 31 tissue culture media studied. A series of experiments carried out to determine the nature of the luteotrophic activity indicate that it is a small $\left(M_{\mathrm{r}}<10000\right)$, heat-labile, lipid-soluble substance that is adsorbed by dextran-coated charcoal. The nature and activity of this factor, together with its synthesis by the early bovine conceptus, suggest that it may have a significant role in stimulating progesterone synthesis by the corpus luteum during early pregnancy.
\end{abstract}

\section{Introduction}

Day 16 is often cited as the day of maternal recognition of pregnancy in the cow, since the transfer of viable Day-16 bovine conceptuses into suitable recipients up to and including Day 16 after ovulation results in maintenance of the corpus luteum and a normal pregnancy (Betteridge $e t$ al., 1980). The Day-16 conceptus is therefore capable of blocking the luteolytic mechanism(s) of the normal oestrous cycle after spending only a short period of time within the uterus. Henricks et al. (1971) and Lukaszewska \& Hansel (1980), however, reported that plasma progesterone concentrations of pregnant cattle were significantly higher than those of non-pregnant cattle as early as Days 9 and 10 after oestrus. Bulman \& Lamming (1978) reported a difference in milk progesterone by Day 13. These findings suggest that some form of maternal recognition of pregnancy occurs during the second week. Thatcher et al. (1985) were able to prolong the life span of the corpus luteum in cycling cattle by intrauterine infusion, on Days 15-18 of the cycle, of "conceptus secretory proteins' harvested from cultures of Day 17-18 bovine conceptuses. However, the plasma progesterone profiles reported indicated a retarded luteal regression, or an antiluteolytic effect, rather than the increased steroidogenesis of the corpus luteum of early pregnancy described by Henricks et al. (1971) and Lukaszewska \& Hansel (1980).

We have attempted, in this study, to identify luteotrophic factors produced by Day 13-18 bovine conceptuses in culture that could be responsible for the increased plasma progesterone concentrations found in early pregnancy.

\section{Materials and Methods}

Superovulation. Superovulation was initiated between Days 8 and 12 of the oestrous cycle by intramuscular administration of $5 \mathrm{mg}$ of a follicle-stimulating hormone preparation (FSH: Burns Biotec Laboratories, Omaha, NE, U.S.A.) twice daily for 4 consecutive days. Prostaglandin (PGF-2a) (Upjohn, Midland, MI, U.S.A.) was administered on the evening of the 3rd and morning of the 4th day of FSH treatment. The superovulated cattle were artificially 
inseminated within $12 \mathrm{~h}$ of the onset of oestrus; usually they were inseminated again $12 \mathrm{~h}$ later and occasionally a third time after an additional $12 \mathrm{~h}$. The inseminated animals were checked daily for signs of oestrus until the day of embryo collection.

Embryo collection and culture. At 13-18 days after insemination the uterus of each cow was flushed with Dulbecco's phosphate-buffered saline (D-PBS, GIBCO, Grand Island, NY, U.S.A.), containing 0.3\% bovine serum albumin (BSA; Sigma Chemical Company, St Louis, MO, U.S.A.), 100 i.u. penicillin $/ \mathrm{ml}$ and $100 \mu \mathrm{g}$ streptomycin $/ \mathrm{ml}$.

The conceptuses were removed from the flushing medium and resuspended in fresh Dulbecco's PBS plus 0.3\% BSA in sterile $90 \times 50 \mathrm{~mm}$ Pyrex evaporation dishes (Corning Glass Works, Corning, NY, U.S.A.). Each conceptus was examined and damaged portions were excised and discarded. The remaining conceptus tissue was washed several times in BSA-free Dulbecco's PBS and resuspended in 5-10 ml Hams F-10 medium (GIBCO) plus penicillin (100 i.u./ $\mathrm{ml}$ )/streptomycin $(100 \mu \mathrm{g} / \mathrm{ml}$ ) in Falcon $60 \mathrm{~mm} \times 15 \mathrm{~mm}$ Petri dishes (Falcon, Oxnard, CA, U.S.A.), which were used for cuiture of the conceptus tissue. Fetal bovine serum (FBS, GIBCO), at a concentration of $2.5 \%$ was added to the medium used for the first day of culture only.

Two methods of culture were attempted. In the first the conceptus was cut at right angles to its long axis into sections $1-4 \mathrm{~mm}$ in length. If the tissue was viable the open ends of the trophoblast sealed within $24 \mathrm{~h}$ in culture and trophoblast vesicles resulted (suspension culture). In the second method the conceptus tissue was supported on a stainless-steel grid platform and medium was added to the level of the lower surface of the grid (organ culture). Attachment of the conceptus tissue resulted within the next $24-48 \mathrm{~h}$. In both systems the media were changed daily, the harvested media centrifuged at $1000 \mathrm{~g}$, and the supernatant collected and stored at $-20^{\circ} \mathrm{C}$.

Dispersed luteal cell incubations. The luteotrophic effects of the harvested culture media were tested in the dispersed bovine luteal cell incubation as described by Hixon \& Hansel (1979). Corpora lutea were enucleated from Holstein heifers under epidural anaesthesia between Days 8 and 12 of the oestrous cycle (oestrus $=$ Day 0 ) through a small incision in the anterior vagina and immediately placed in chilled tissue-culture medium, Medium 199 (GIBCO). The luteal cells were dispersed in Medium 199 with collagenase. The dispersed cells were washed several times with fresh medium and filtered through artist's silk for removal of undissociated tissue and clumps of luteal cells. A representative sample of the cells was stained with $0 \cdot 2 \%$ trypan blue in balanced salt solution for determination of viability based on dye exclusion (Tennant, 1974). The live cells were diluted to a final concentration of $0.25-1.0 \times 10^{6} \mathrm{cells} / \mathrm{ml}$ Medium 199 , and $1.2 \mathrm{ml}$ was pipetted into each incubation tube.

After a preincubation of $15 \mathrm{~min}$ in a $37^{\circ} \mathrm{C}$ water bath with gentle shaking in an atmosphere of $95 \%$ air and $5 \%$ $\mathrm{CO}_{2}$, an aliquant of cell suspension $(200 \mu \mathrm{l})$ was collected and centrifuged at $1000 \mathrm{~g}$ to concentrate the cells. The supernatant was then decanted and stored at $-20^{\circ} \mathrm{C}$ until determination of initial progesterone concentration in the medium was carried out. This was taken as the progesterone concentration at time zero.

In each experiment there were two standard treatments consisting of addition of (a) $100 \mu 1$ Medium 199 and (b) $5 \mathrm{ng} \mathrm{LH}$ in $100 \mu \mathrm{l}$ Medium 199. The test substances were added in $100 \mu \mathrm{l}$ volumes ( $8 \%$ of final volume). After the incubation period, the samples were centrifuged at $1000 \mathrm{~g}$ to concentrate the cells and the supernatants were decanted and frozen at $-20^{\circ} \mathrm{C}$.

The differences between the concentrations of progesterone in samples collected at time zero and the concentrations in samples collected after $2 \mathrm{~h}$ of incubation were considered to represent secretion of progesterone by luteal cells during the incubation.

Radioimmunoassay for progesterone. The method described by Milvae (1978) was used for progesterone radioimmunoassay in unextracted incubation media. The lower limit of sensitivity was $0.125 \mathrm{ng} / \mathrm{ml}$, the interassay coefficient of variation was $14.2 \%$ at $120 \mathrm{pg} / 100 \mu \mathrm{l}$, and the intra-assay coefficient of variation was $3.9 \%$ over a concentration range of 12.5 to $1600 \mathrm{ng}$.

Progesterone concentration in the harvested culture media. To establish that the mean progesterone concentration measured in the luteal cell incubation samples was not due to progesterone already present in the conceptus tissue culture medium being tested, the harvested media were assayed: 23 samples of $100 \mu$ l each were tested in duplicate.

Luteotrophic activity of conceptus tissue culture media. Luteotrophic activity of each medium sample was measured in 3-5 replicates of $100 \mu \mathrm{l}$ each added to a luteal cell incubation.

All characterization procedures outlined below were limited to culture media that showed significant luteotrophic activity $(P<0.05)$ when assayed in the dispersed luteal system and to which no FBS had been added.

Ammonium sulphate precipitation of conceptus tissue culture medium. Precipitations with $20 \%$ and $60 \%$ ammonium sulphate $\left(\left(\mathrm{NH}_{4}\right)_{2} \mathrm{SO}_{4}\right)$ were carried out on 4 different culture media at $4^{\circ} \mathrm{C}$. These media had been harvested on Day 2 (2), Day 4 and Day 10 of culture. The resulting fractions $(20 \%, 60 \%$ and residual volume) were dialysed against distilled water for $24 \mathrm{~h}$ at $4{ }^{\circ} \mathrm{C}$ and further dialysed against $0.9 \% \mathrm{NaCl}$ using dialysis tubing with a molecular weight cut-off of 14000 (Spectrapore 2, 12 000-14000 $M_{\mathrm{r}}$ cutoff; Spectrum Medical Industries, Los Angeles, CA, U.S.A.). Each of the precipitates was resuspended in $0.9 \% \mathrm{NaCl}$ to the original medium volume and, with the residual fraction, was assayed for luteotrophic activity in 4 replicates of $100 \mu \mathrm{l}$ each when added to a dispersed luteal cell incubation as described above.

Heat treatment. Medium harvested on Day 3 of culture was maintained at $60^{\circ} \mathrm{C}$ for $30 \mathrm{~min}$ in a water bath and tested for luteotrophic activity. 
Further characterization studies on conceptus culture media. Conceptus culture media harvested on Day 4 and Day 7 , which had significant luteotrophic activity, were pooled and separated into fractions of $M_{\mathrm{r}}<10000$ and $>10000$ using an Amicon C-10 Centricon filter (Amicon Corp., Danvers, MA, U.S.A.). The $M_{\mathrm{r}}>10000$ fraction was concentrated to $500 \mu \mathrm{l}$ in $0.9 \%(\mathrm{w} / \mathrm{v})$ PBS, resulting in a 4-fold increase in concentration and assayed for luteotrophic activity. Half of the $M_{\mathrm{r}}<10000$ fraction (which remained at its original concentration) was assayed for luteotrophic activity. Both fractions $\left(M_{\mathrm{r}}<10000\right.$ and $\left.M_{\mathrm{r}}>10000\right)$ were tested in 4 replicates of $100 \mu \mathrm{l}$ each.

The remainder of the $M_{\mathrm{r}}<10000$ fraction was subjected to the Folch procedure for lipid extraction (Folch et al., 1951, 1957). Lipid extraction was also carried out on Hams F-10 medium and Hams F-10 medium plus $2 \cdot 5 \%$ fetal bovine serum. Each lipid was resuspended in Medium 199 by sonication and tested for luteotropic activity in 5 replicates of $100 \mu$ leach.

Media harvested on Days 4 and 7 of culture were divided into fractions of $M_{\mathrm{r}}<10000$ and $>10000$. Dextrancoated charcoal was added to an aliquant of the $M_{\mathrm{r}}<10000$ fraction and left for $15 \mathrm{~min}$ at $4^{\circ} \mathrm{C}$. The suspension was centrifuged at $2000 \mathrm{~g}$ for $15 \mathrm{~min}$ and the supernatant was collected and tested for luteotrophic activity, along with the untreated $M_{\mathrm{r}}<10000$ and $M_{\mathrm{r}}>10000$ fractions in 4 replicates of $100 \mu \mathrm{l}$ each.

Enzymic digestion was carried out on the remainder of the $M_{\mathrm{r}}<10000$ fraction of culture media. Lyophilized trypsin (Worthington Biochemical Corporation, Freehold, NJ, U.S.A.) and chymotrypsin (Sigma) were dissolved in D-PBS in equal amounts and added in a 10:1 (w/w) protein:enzyme ratio to culture media and incubated for $3 \mathrm{~h}$ at $37^{\circ} \mathrm{C}$. Protein in the culture media was determined from spectrophotometric absorbances at $260 \mathrm{~nm}$ and $280 \mathrm{~nm}$. Lyophilized trypsin inhibitor (Millipore Corporation, Freehold, NJ, U.S.A.) dissolved in D-PBS was added to the incubation mixture and allowed to stand for $30 \mathrm{~min}$ at room temperature before assaying for luteotrophic activity in 4 replicates of $100 \mu l$ each.

Statistics. One- and two-way analyses of variance were used to assess the data. Whenever possible, data for the same treatments carried out in different experiments were combined to increase the number of replicates per treatment. To combine data in this manner, the results of the treatments for the 2 or more experiments were compared using two-way analysis of variance. The data were converted to units of 'stimulation index' (progesterone treated/ progesterone control) to reduce the variation in response between batches of corpus luteum cells. If there was no statistically significant difference present in the response for treatments across experiments, the data were combined. A one-way analysis of variance was then carried out on the combined data sets. If the differences between treatments were significant, the individual means were compared by Duncan's multiple range test. The results are given as mean and s.e. and the significance of response of each treatment over the control response is given at the $P<0.05$ or $P<0 \cdot 0$ I levels. The number of different conceptus tissue culture media is indicated by $n$.

\section{Results}

Altogether, 72 embryos ranging in age from 13 to 18 days were flushed non-surgically from donor animals and 31 cultures were initiated; 18 were organ cultures and 13 suspension cultures. All cultures remained viable, based on gross appearance, from a minimum of 2 to a maximum of 54
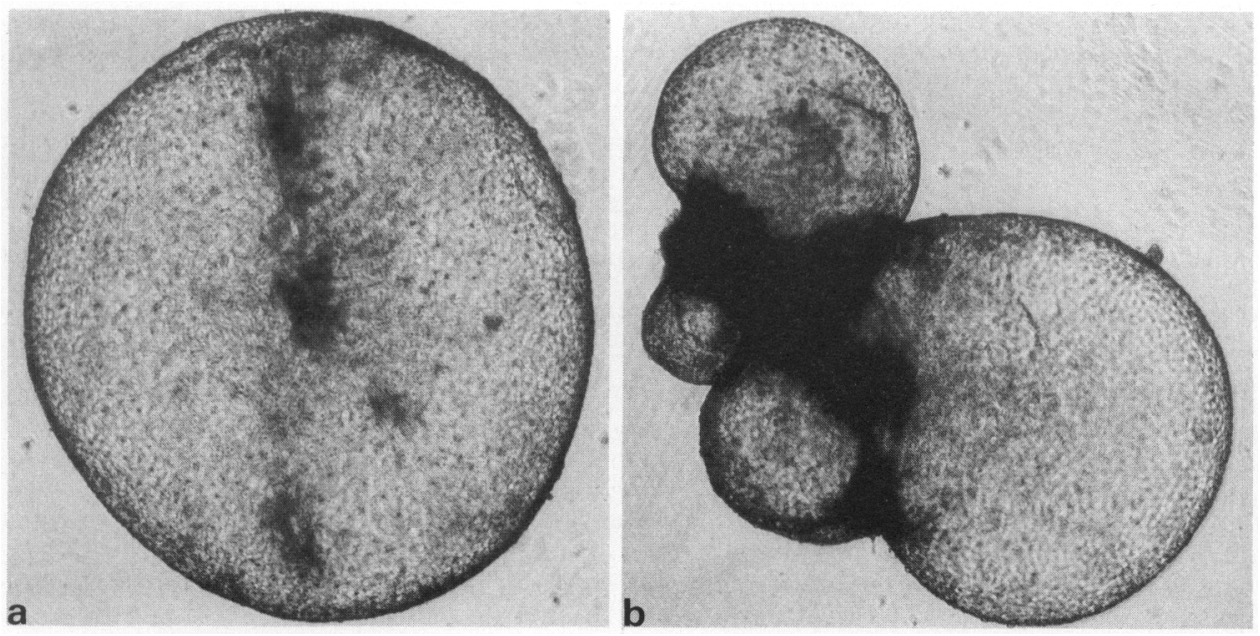

Fig. 1. Trophoblast vesicles from a Day 18 bovine conceptus after culture for 7 days: (a) single vesicle, (b) fusion of several vesicles resulting in a single multilobed vesicle. $\times 22$. 


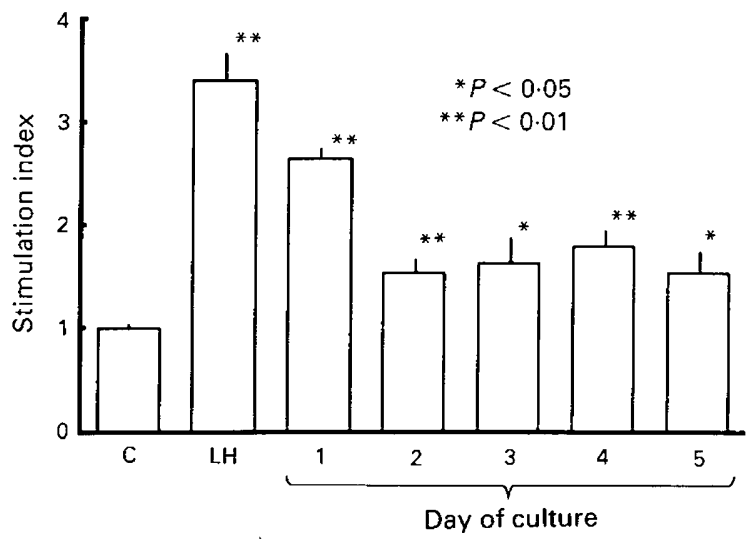

Fig. 2. Net progesterone synthesis (mean \pm s.e., $n=2)$ by bovine luteal cells $\left(\mathrm{ng} / 10^{6}\right.$ cells $/ 2 \mathrm{~h}$ ) in response to Medium 199 (C), $5 \mathrm{ng} \mathrm{LH}(\mathrm{LH})$ or media collected during sequential days of tissue culture. Data are expressed in units of stimulation index (progesterone treated/ progesterone control).

days with a mean of 12 days. Trophoblast vesicles developed in both systems; in the suspension culture they were freely floating in medium, with 2-3 vesicles often adherent (Fig. 1). In the organ culture, pedunculated trophoblast vesicles formed beneath the stainless-steel grid; these would occasionally bud off into the medium.

\section{Progesterone concentration in the harvested culture medium}

Progesterone was assayed in duplicate $100 \mu \mathrm{l}$ aliquants of 23 different samples. The concentrations ranged from non-detectable $(n=8)$ to $50.9 \mathrm{ng} / \mathrm{ml}$ with a mean of $12.8 \pm 3.2 \mathrm{ng} / \mathrm{ml}$. Since $100 \mu \mathrm{l}$ culture medium were added to all of the luteal cell incubations, these results indicate that a maximum of $5 \cdot 1 \mathrm{ng}$ progesterone would have been added to the culture medium. Contributions of this magnitude could not therefore explain the relatively large increases in progesterone synthesis $(90 \pm 18 \mathrm{ng} / \mathrm{ml})$ that occurred during the 2-h incubation periods after addition of the embryo culture media.

\section{Luteotrophic activity of conceptus tissue culture media}

Significant luteotrophic activity $(P<0.05)$ was present, at some period, in the media of $80 \%$ of the 31 conceptus tissue cultures studied. Luteotrophic activity was most consistently found in media harvested during the first 5 days of culture. The culture media of both the organ culture system and the suspension culture system contained luteotrophic activity. The combined data for luteotrophic activity of harvested media from two different conceptus tissue cultures are shown in Fig. 2. Although Day 1 media (FBS present) contained the highest level of luteotrophic activity $(P<0.01)$, significant activity persisted during the first 5 days of culture in the absence of FBS ( $P<0.05$ for Days 3 and 5; $P<0.01$ for Days 2 and 4 ). The presence of $2.5 \%$ FBS in the culture media had no effect on progesterone secretion over the control media level alone.

\section{Ammonium sulphate precipitation of conceptus tissue culture media}

The results obtained when the $20 \%$ and $60 \%\left(\mathrm{NH}_{4}\right)_{2} \mathrm{SO}_{4}$ precipitates or the residual fractions of 4 culture media were added to incubations of bovine luteal cells are shown in Fig. 3. No significant stimulation of progesterone synthesis resulted, indicating that the active substance(s) is not a protein. 
Effect of heat treatment on the luteotrophic activity of culture media

As shown in Table 1, maintaining a culture media at $60^{\circ} \mathrm{C}$ for $30 \mathrm{~min}$ resulted in a significant loss of the stimulatory activity present in the original sample (progesterone $\mathrm{ng} / 10^{6} \mathrm{cells} / 2 \mathrm{~h}$ : control, $86 \pm 1 \cdot 7$; culture medium, $131 \pm 5 \cdot 5$; culture medium after heat treatment, $77 \pm 4 \cdot 5$; $P<0.05)$.

\section{Further characterization studies on conceptus culture media}

Fractionation of the culture media containing luteotrophic activity revealed that the luteotrophic activity was present only in the $M_{\mathrm{r}}<10000$ fraction. Addition of the entire spent culture medium, or the $M_{\mathrm{r}}<10000$ fraction resulted in significantly increased progesterone synthesis over the control tissue $\left(P<0 \cdot 01\right.$, Fig. 4). Figure 4 also shows that a lipid extract of the $M_{\mathrm{r}}<10000$ fraction contained all of the luteotrophic activity $(P<0.01)$. In a separate experiment, lipid extracts of Hams F-10 medium, with or without $2.5 \%$ FBS, failed to stimulate progesterone production above the control level (data not shown, $P>0.05$ ).

Dextran-coated charcoal has the ability to bind steroids and other small molecules in solution. Since the luteotrophin appeared to be a lipid (i.e. not precipitated by ammonium sulphate and extractable by organic solvents), the effect of the addition of dextran-coated charcoal on the luteotrophic activity of the culture medium was studied. The combined mean progesterone concentrations for 2 separate experiments are shown in Fig. 5. The luteotrophic activity of the $M_{\mathrm{r}}<10000$ fraction of the culture medium was removed by the treatment $(P<0.05)$.

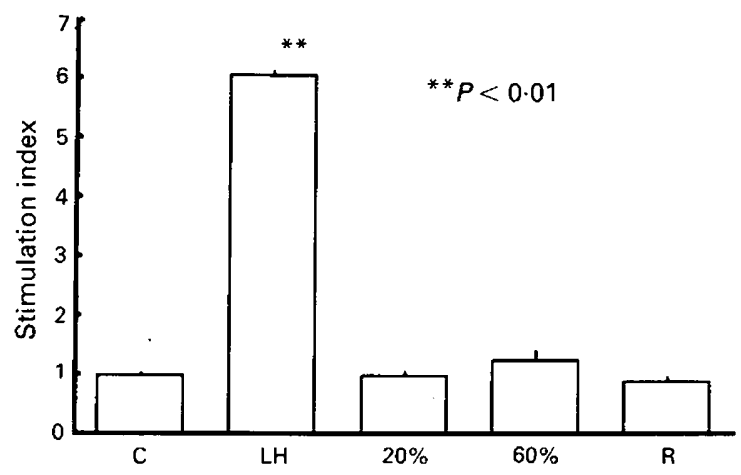

Fig. 3. Net progesterone synthesis (mean \pm s.e., $n=4$ ) by bovine luteal cells ( $\mathrm{ng} / 10^{6} \mathrm{cells} / 2 \mathrm{~h}$ ) in response to Medium $199(\mathrm{C}), 5 \mathrm{ng} \mathrm{LH}(\mathrm{LH})$, ammonium sulphate precipitates $(20 \%, 60 \%)$, or the residual fractions $(R)$ of culture media. Data are expressed in units of stimulation index (progesterone treated/progesterone control).

Table 1. Net progesterone synthesis $(\mathrm{ng} / \mathrm{ml})$ by $10^{6}$ dispersed bovine luteal cells from 1 cow over $2 \mathrm{~h}$ when treated with Medium 199, LH, or conceptus tissue culture medium before or after heating to $60^{\circ} \mathrm{C}$ for $30 \mathrm{~min}$

\begin{tabular}{lrc}
\hline Treatment & Mean & s.e. \\
\hline M 199 & 86 & 1.7 \\
5 ng LH & $* * 359$ & 17 \\
Culture medium & $* 131$ & 5.5 \\
Culture medium after heating & 77 & 4.5 \\
$\quad$ at $60^{\circ} \mathrm{C}$ for 30 min & & \\
\hline${ }^{*} P<0.05 ;{ }^{*} P<0.01$. &
\end{tabular}




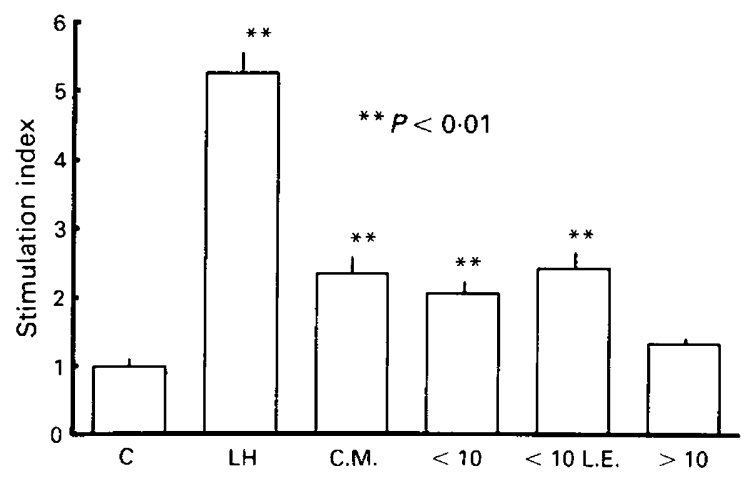

Fig. 4. Net progesterone synthesis (mean \pm s.e., $n=2)$ by bovine luteal cells $\left(\mathrm{ng} / 10^{6}\right.$ cells $/ 2 \mathrm{~h}$ ) in response to Medium 199 (C), $5 \mathrm{ng} \mathrm{LH} \mathrm{(LH),} \mathrm{culture} \mathrm{media} \mathrm{(C.M.),} M_{\mathrm{r}}<10000$ fractions of culture media ( $<10$ ), lipid extracts of the $M_{\mathrm{r}}<10000$ fractions ( $<10 \mathrm{~L}$.E.) or $M_{\mathrm{r}}$ $>10000$ fractions of culture media $(>10)$. Data are expressed in units of stimulation index (progesterone treated/progesterone control).

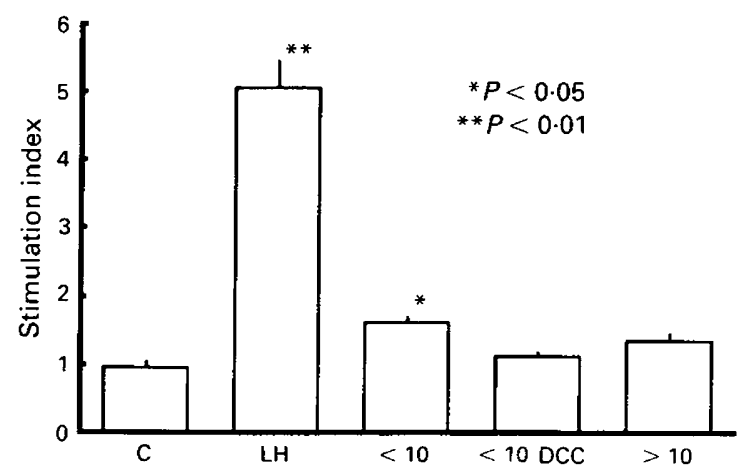

Fig. 5. Net progesterone synthesis (mean \pm s.e., $n=2$ ) by bovine luteal cells (ng/10 6 cells $/ 2 \mathrm{~h}$ ) in response to Medium $199(\mathrm{C}), 5 \mathrm{ng} \mathrm{LH}(\mathrm{LH}), M_{\mathrm{r}}<10000$ fractions of culture media $(<10)$, before or after addition of dextran-coated charcoal ( $<10 \mathrm{DCC}$ ), or an $M_{\mathrm{r}}>10000$ fraction of culture media $(>10)$. Data are expressed in units of stimulation index (progesterone treated/ progesterone control).

Enzymic digestion of the $M_{\mathrm{r}}<10000$ fraction was carried out to determine whether the activity may be due to a highly lipophilic peptide or small lipoprotein. The luteotrophic activity of the $M_{\mathrm{r}}$ $<10000$ fraction of the culture medium was not significantly reduced by trypsin and chymotrypsin digestion (progesterone, $\mathrm{ng} / 10^{6}$ cells $/ 2 \mathrm{~h}$ : control, $92 \pm 16 ; M_{\mathrm{r}}<10000,192 \pm 15 ; M_{\mathrm{r}}<10000$ after digestion, $170 \pm 14 ; P>0.05$ for $M_{\mathrm{r}}<10000$ vs $M_{\mathrm{r}}<10000$ after digestion).

\section{Discussion}

In the present study we report the successful culture of Day 13-18 bovine conceptus tissue for periods up to 54 days. These culture systems therefore permit examination of the potential role(s) of conceptus-derived factors in maintenance of the corpus luteum of early pregnancy.

Luteotrophic activity, as measured by ability to stimulate progesterone synthesis by luteal cells in vitro, was identified in the harvested media from the bovine conceptus tissue cultures. The 
activity was found in the $M_{\mathrm{r}}<10000$ fraction, was not precipitated by $\left(\mathrm{NH}_{4}\right)_{2} \mathrm{SO}_{4}$ and was not destroyed by protease activity. The luteotrophin therefore does not appear to be proteinaceous in nature.

The activity was extracted by lipid solvents. Dextran-coated charcoal bound and removed the activity from the culture medium. These results suggest that the luteotrophin is lipid, in total or in part. Although heating the medium to $60^{\circ} \mathrm{C}$ for $30 \mathrm{~min}$ destroyed the activity, this is not an unexpected result for some lipids. The lipid class to which the luteotrophic substance belongs has not yet been identified. These results are in agreement with and extend the findings of Beal et al. (1981) who found a heat-labile dialysable luteotrophin(s) in homogenates of Day-18 bovine conceptuses.

Other evidence indicating the presence of a luteotrophin, attributable directly or indirectly to the conceptus as early as the 2nd week of pregnancy, includes the previously cited data of Henricks et al. (1971) and Lukaszewska \& Hansel (1980), who found a significant difference in the plasma progesterone concentrations between pregnant and non-pregnant cattle by Day 10 after insemination. In sheep, there is indirect evidence for a conceptus-derived factor that increases the functional capacity of the corpus luteum in early pregnancy. Pratt et al. (1977) reported that exogenously administered PGF-2 $\alpha$ on Day 13 after oestrus was less effective as a luteolysin in pregnant than in non-pregnant ewes.

An early pregnancy luteotrophin may also exist in women, since Dlugi et al. (1984) reported finding significantly higher progesterone titres in pregnant than in non-pregnant women after invitro fertilization and embryo transfer. There is also increasing evidence for the existence of "early pregnancy factors' in other species, including the observations of O'Neill (1985) and O'Neill et al. (1985) on embryo-derived platelet activating factors (PAF) in mice and women. Thrombocytopenia, a result of platelet activation, occurs during the first 7 days of pregnancy and is dependent upon the presence of fertilized ova and their production of PAF, PAF is a small molecule (1-0-alkyl-2-acetylSn-glyceryl 3 phosphocholine) extractable in chloroform; it is not known to possess luteotrophic properties.

The results of these experiments suggest that the active principle could be a steroid. Blastocysts of Day-16 pregnant cows produce progesterone, oestradiol-17 $\beta$ and testosterone (Shemesh et al., 1979). However, it has been shown in cattle that exogenous progesterone inhibits corpus luteum development, shortens the oestrous cycle and reduces CL weights if given early in the cycle before endogenous progesterone has begun to rise (Ray et al., 1961; Woody et al., 1967; Harms \& Malven, 1969). Administration of oestrogen in the unconjugated (Greenstein et al., 1958; Wiltbank et al., 1961) or conjugated form (oestrone sulphate; Eley et al., 1979a) is also luteolytic in the cow, an important point, since oestrone sulphate is the major form of oestrogen in the pregnant cow.

Androstenedione and testosterone have not been tested for luteotrophic activity in vitro. Immunization of ewes against androstenedione has been reported to result in increased early embryonic mortality (Boland et al., 1986). Since there is extensive metabolism of androstenedione to $5 \beta$-reduced compounds by the bovine conceptus during early pregnancy (Eley et al., 1979b) this group of compounds may warrant further study.

PGE-2 and PGI-2 have often been cited as possible luteotrophic signals from the conceptus to the dam to invoke maternal recognition of pregnancy in the cow and sheep (Pratt et al., 1977; Silvia et al., 1984). However, the luteotrophic factor described does not appear as labile as the prostanoids (half life of $15 \mathrm{sec}$ in vivo for PGF-2 $\alpha$ and PGE-2; Green et al., 1981; half life of $10 \mathrm{~min}$ at $37^{\circ} \mathrm{C}$ for PGI-2; Samuelsson, 1978). Harvested media maintained at room temperature for $1-2 \mathrm{~h}$ before addition to the in-vitro assay did not lose their activity.

It would appear that the early pregnancy conceptus-derived luteotrophin that we have identified in a conceptus tissue culture system is not essential for maintenance of the CL of pregnancy, since transfer of the Day-16 bovine conceptus to a cycling animal can result in maintenance of the CL of the recipient (Betteridge et al., 1980). The low molecular weight and lipid-soluble properties of the luteotrophin, which would facilitate rapid absorption by the endometrium, and its produc- 
tion during the accepted period of maternal recognition of pregnancy, suggest that it may be involved in increasing the functional capacity of the early $\mathrm{CL}$ and in embryo survival.

We thank Raymond Saatman for excellent technical assistance; and Mrs Virginia Slator for help with the preparation of the manuscript. This work was supported by a grant from the National Association of Animal Breeders, and the Northeast Regional Research Project-NE-72, entitled Control and Improvement of Reproduction in the Bovine Female.

\section{References}

Beal, W.E., Lukaszewska, J.H. \& Hansel, W. (1981) Luteotropic effects of bovine blastocysts. J. Anim. Sci. 52, 567-574.

Betteridge, K.J., Eaglesome, M.D., Randall, G.C.B. \& Mitchell, D. (1980) Collection, description and transfer of embryos from cattle 10-16 days after oestrus. J. Reprod. Fert. 59, 205-216.

Boland, M.P., Nancarrow, C.D., Murray, J.D., Scaramuzzi, R.J., Sutton, R., Hoskinson, R.M. \& Hazelton, I.G. (1986) Fertilization and early embryonic development in androstenedione-immunized Merino ewes. J. Reprod. Fert. 78, 423-431.

Bulman, D.C. \& Lamming, G.E. (1978) Milk progesterone levels in relation to conception, repeat breeding and factors influencing acyclicity in dairy cows. $J$. Reprod. Fert. 54, 447-458.

Dlugi, A.M., Laufer, N., DeCherney, A., MacLusky, N., Haseltine, F., Polan, M., Mezer, H., Tarlatzis, B. \& Naftolin, F. (1984) The preovulatory and luteal phase of conception cycles following in vitro fertilization and embryo transfer. Fert. Steril. 41, 530-537.

Eley, R.M., Thatcher, W.W. \& Bazer, F.W. (1979a) Luteolytic effect of oestrone sulphate on cyclic beef heifers. J. Reprod. Fert. 55, 191-193.

Eley, R.M., Thatcher, W.W., Blazer, F.W. \& Fields, M.J. (1979b) Metabolism of progesterone and androstenedione in vitro by bovine endometrium and conceptus. J. Anim. Sci. 49 (Suppl. 1), 294, Abstr.

Folch, J., Ascoli, I., Lees, M., Meath, A.A. \& LeBaron, F.N. (1951) Preparation of lipid extracts from brain tissue. J. biol. Chem. 191, 833-841.

Folch, J., Lees, M. \& Sloan Stanley, G.H. (1957) A simple method for the isolation and purification of total lipids from animal tissues. J. biol. Chem. 226, 497-509.

Green, K., Christensen, N. \& Bygdeman, M. (1981) The chemistry and pharmacology of prostaglandins, with reference to human reproduction. J. Reprod. Fert. 62, 269-281.

Greenstein, J.S., Murray, R.W. \& Foley, R.C. (1958) Effect of exogenous hormones on the reproductive process of the cycling dairy heifer. J. Dairy Sci. 41, 1834, Abstr.

Harms, P.G. \& Malven, P.V. (1969) Modification of bovine luteal function by exogenous oxytocin and progesterone. J. Anim. Sci. 29, 25-29.

Henricks, D.M., Lamond, D.R., Hill, J.R. \& Dickey, J.F. (1971) Plasma progesterone concentrations before mating and in early pregnancy in the beef heifer. $J$. Anim. Sci. 33, 450-454.

Hixon, J.E. \& Hansel, W. (1979) Effects of prostaglandin $F_{2 \alpha}$, estradiol and luteinizing hormone in dispersed cell preparations of bovine corpora lutea. In Ovarian
Follicular and Corpus Luteum Function, pp. 613-620. Eds C. P. Channing, J. M. Marsh \& W. A. Sadler. Plenum Press, New York.

Lukaszewska, J. \& Hansel, W. (1980) Corpus luteum maintenance during early pregnancy in the cow. $J$. Reprod. Fert. 59, 485493.

Milvae, R.A. (1978) The effects of oxytocin on the secretion of estradiol, progesterone, luteinizing hormone and prostaglandin $F$ in heifers. M.Sc. thesis, Cornell University.

O'Neill, C. (1985) Thrombocytopenia is an initial maternal response to fertilization in mice. J. Reprod. Fert. 73, 559-566.

O’Neill, C., Pike, I., Porter, R., Gidley-Baird, A., Sinosich, M.J. \& Saunders, D. (1985) Maternal recognition of pregnancy prior to implantation: Methods for monitoring embryonic viability in vitro and in vivo. Ann. N.Y. Acad. Sci. 442, 429-439.

Pratt, B.R., Butcher, R.L. \& Inskeep, E.K. (1977) Antiluteolytic effect of the conceptus and of prostaglan$\operatorname{din} \mathrm{E}_{2}$ in ewes. J. Anim. Sci. 46, 784-791.

Ray, D.E., Emmerson, M.A. \& Melampy, R.M. (1961) Effect of exogenous progesterone on reproductive activity in the beef heifer. J. Anim. Sci. 20, 373-379.

Samuelsson, B. (1978) Prostaglandins and thromboxanes. Recent Prog. Hormone Res. 34, 239-258.

Shemesh, M., Milaguir, F., Ayalon, N. \& Hansel, W. (1979) Steroidogenesis and prostaglandin synthesis by cultured bovine blastocysts. J. Reprod. Fert. 56, $181-185$.

Silvia, W.J., Ottobre, J.S. \& Inskeep, E.K. (1984) Concentrations of prostaglandins $\mathrm{E}_{2}, \mathrm{~F}_{2 \alpha}$, and 6-ketoprostaglandin $F_{1 \alpha}$ in the utero-ovarian venous plasma of non-pregnant and early pregnant ewes. Biol. Reprod. 30, 936-944.

Tennant, R.J. (1974) Evaluation of trypan blue techniques for determination of cell viability. Transplantation 2, $685 \quad 696$.

Thatcher, W.W., Knickerbocker, J.J., Bartol, F.F., Bazer, F.W., Roberts, R.M. \& Drost, M. (1985) Maternal recognition of pregnancy in relation to the survival of transferred embryos: endocrine aspects. Theriogenology 23, 129-143.

Wiltbank, J.N., Ingalls, J.E. \& Rowden, W.W. (1961) Effects of various forms and levels of estrogens alone or in combinations with gonadotrophins on the estrous cycle of beef heifers. J. Anim. Sci. 20, 341-346.

Woody, C.O., First, N.L. \& Pope, A.L. (1967) Effect of exogenous progesterone on estrous cycle length. $J$. Anim. Sci. 29, 139-141.

Received 18 November 1986 